\title{
TINJAUAN YURIDIS TENTANG PATEN BERDASARKAN UNDANG-UNDANG PATEN NOMOR 14 TAHUN 2001
}

\author{
Mashunah Hanafi \\ Fakultas Syariah dan Ekonomi Islam IAIN Antasari, Jl. Jenderal Ahmad Yani Km 4,5 Banjarmasin \\ e-mail: mahsunah.hanafi@gmail.com
}

\begin{abstract}
Paten is an intellectual work which is protected by the State through the law or intellectual property rights, given to the inventors for improving their inventions during the period of time. Inventor is a person or a group of people who has the same idea to run the invention as a solution for specific problem in the field of technology that could significantly improve or simply adjust their products and processes.
\end{abstract}

\begin{abstract}
Abstrak: Paten sebagai salah satu karya intelektual yang dilindungi dalam hak kekayaan intelektual, yang diberikan Negara kepada inventor atas hasil invensinya, yang masuk selama waktu tertentu melaksanakan sendiri inventasinya tersebut atau memberikan persetujuannya kepada pihak lain untuk melaksanakannya. Inventor adalah seseorang yang secara sendiri atau beberapa orang secara bersamasama melaksanakan ide yang dituangkan dalam kegiatan yang melahirkan invensi (penemuan). invensi adalah ide inventor yang dituangkan kedalam suatu kegiatan pemecahan masalah yang spesifik di bidang teknologi, dapat berubah produk atau proses atau penyempurnaan dan pengembangan produk atau proses.
\end{abstract}

Kata kunci: Paten, invensi, investor.

\section{Pendahuluan}

Pengaruh perkembangan teknologi sangat besar terhadap kehidupan sehari-hari dan dalam beberapa dasawarsa terakhir ini, perkembangan tersebut sangat pesat. Perkembangan itu tidak hanya di bidang teknologi tinggi, seperti komputer, elektro, telekomunikasi, dan bioteknologi, tetapi juga di bidang mekanik, kimia, atau lainnya. Bahkan, sejalan dengan itu, makin tinggi pula kesadaran masyarakat untuk meningkatkan pendayagunaan teknologi yang sederhana. Bagi Indonesia, sebagai negara yang memiliki sumber daya alam yang melimpah, pentingnya peranan teknologi merupakan hal yang tidak terbantah. Namun, perkembangan teknologi tersebut belum mencapai sasaran yang diinginkan. Hal ini telah dirumuskan secara jelas dalam Ketetapan Majelis Permusyawaratan Rakyat Nomor IV/MPR/1999 tentang Garisgaris Besar Haluan Negara, antara lain yang menyatakan bahwa pengembangan teknologi belum dimanfaatkan secara berarti dalam kegiatan ekonomi, sosial, dan budaya sehingga belum memperkuat kemampuan Indonesia dalam rangka menghadapi persaingan global. Untuk meningkatkan perkembangan teknologi, diperlukan adanya suatu sistem yang dapat merangsang perkembangan teknologi dalam wujud perlindungan terhadap karya intelektual, termasuk Paten yang sepadan.

Dalam kaitan itu, walaupun Indonesia telah memiliki Undang-undang Paten, yaitu Undangundang Nomor 6 Tahun 1989 tentang Paten (Lembaran Negara Tahun 1989 Nomor 39) jo Undang-undang Nomor 13 Tahun 1997 (Lembaran Negara Tahun 1997 Nomor 30) (selanjutnya disebut Undang-undang Paten-lama) dan pelaksanaan Paten telah berjalan, dipandang perlu melakukan perubahan terhadap Undangundang Paten lama itu. Di samping itu, masih ada beberapa aspek dalam Agreement on TradeRelated Aspects of Intellectual Property Rights (selanjutnya disebut Persetujuan TRIPs) yang belum ditampung dalam Undang-undang Paten tersebut. Seperti diketahui, Indonesia meratifikasi Agreement Establishing the World Trade Organization (Pembentukan Organisasi Perdagangan Dunia), selanjutnya disebut World Trade Organization, dengan Undang-undang Nomor 7 Tahun 1994 tentang Pengesahan Agreement Establishing The World Trade Organization (Lembaran Negara Tahun 1994 Nomor 57) dan Persetujuan TRIPs merupakan salah satu lampiran dari perjanjian ini. Mengingat lingkup perubahan serta untuk memudahkan penggunaannya oleh masyarakat, undang-undang Paten ini disusun secara 
menyeluruh dalam satu naskah (single text) pengganti Undang-undang Paten-lama. Dalam hal ini, ketentuan dalam Undang-undang Patenlama, yang substansinya tidak diubah dituangkan kembali ke dalam Undang-undang ini. Secara umum perubahan yang dilakukan adalah undangundang Paten-lama meliputi penyempurnaan, penambahan, dan penghapusan.

Untuk itu dalam tulisan ini akan dibahas mengenai Tinjauan Yuridis tentang Paten berdasarkan Undang-Undang Paten Nomor 14 Tahun 2001, terkait dengan permasalahan semakin pesatnya perkembangan perdagangan di Indonesia sehingga mempengaruhi pertumbuhan perekonomian Negara yang salah satunya terkait dengan penanaman modal asing atau invesitor

\section{Sejarah Paten di Indonesia}

Paten telah dikenal diIndonesia sejak zaman penjajahan Belanda. Istilah yang dipakai untuk Paten oleh pemerintah Hindia Belanda saat itu adalah oktrooi yang didasarkan pada peraturan Hindia Belanda ocrtooiwet S.1910-33yis.S.1911. 33,S.1922-54 yang mulai berlaku 1 Juli 1912.1 Peraturan ini diikuti pula dengan adanya Reglement Industriele Eigendom 1912 yang mengesahkan pelaksanaan paten, merek, dan desain dengan mengacu kepada peraturan-peraturan serupa yang berlaku di Belanda. ${ }^{2}$

Menurut Ocrtooiwet, apabila suatu pertemuan hendak dimintakan hak Oktrooi, seluruh dokumen permohonannya akan dikirim ke Den Haag. Biro Paten di Belanda itulah yang akan memberikan oktrooi kepada si pemohon. Octrooi Raad atau Dewan Oktrooi yang mempunyai peranaan dalam hal-hal yang berkaitan dengan permohonan dan pemberian hak paten ini juga berkedudukan di Belanda. ${ }^{3}$

Di Hindia Belanda hanya dikenal kantor cabang atau kantor pembantu dari Bureau Industrielle Eigendom (biro hak milik) di Belanda. Kantor ini berada dibawah koordinasi Departemenvan Justitie dan hanya mengurus masalah

1 Muhammad Djumhana dan R. Djubaedillah, Op.Cit., hlm. 104.

2 Insan Budi Maulana, "Penerapan Paten Sejak UU Paten No.6 Tabun 1989 Hingga UU Paten No.13 Tabun 1997: Pengalaman Indonesia Selama ini", Kapita Selekta Hak Kekayaan IntelektualI. 2000, Yayasan Klinik HaKI Jakarta-PSHFHU II Yogyakarta, Yogyakarta, hlm. 1.

3 Sudargo Gautama, Segi-segi Hukum Hak Milik Intelektual, PT. Eresco, Bandung, 1990, hlm. 1. pendaftaran merek dagang. ${ }^{4}$ Kemudian kantor cabang tersebut menjelma menjadi Direktorat Jenderal Hak Merek (HPCM), dan sekarang dirubah dengan Direktorat Jenderal Hak Kekayaan Intelektual (HaKI) yang berada dibawah Departemen Kehakiman dan HAM.

Setelah Indonesia merdeka, Octrooiwet tersebut dinyatakan tidak berlaku lagi. Hal itu disebabkan kewenangan pemberian paten menurut undangundang tersebut berada di Octrooi Raad Belanda, dan hal itu dirasakan tidak sesuai dengan kedaulatan Negara yang merdeka. Pernyataan tidak berlaku Octrooiwet tersebut tidak diteruskan dengan pembentukan undang-undang yang baru. Sebagai jalan keluarnya, Menteri Kehakiman RI mengeluarkan pengumuman tanggal 12 Agustus 1953 Nomor J.S.5/41/4.BN. 1955-69 guna menampung permintaan paten dalam negeri, dan pengumuman Menteri Kehakiman tanggal 29 Oktober 1953 untuk menampung permintaan paten luar negeri. ${ }^{5}$

Dalam pengumuman tanggal 29 Oktober 1953 tersebut dinyatakan bahwa Kementerian Kehakiman untuk sementara diperbolehkan menerima permintaan paten, akan tetapi proses permintaan Paten tersebut akan dilakukan setelah Undang-Undang Paten yang baru berlaku. ${ }^{6}$ Adanya pendaftaran Paten tersebut tidak memberi hak kepada pendaftar, namun pendaftaran itu menyatakan adanya suatu invensi yang telah dimiliki seseorang. ${ }^{7}$

Sebelum memiliki Undang-Undang Paten, Indonesia telah meratifikasi konvensi internasional di bidang Paten, yaitu konvensi Paris untuk Perindungan Hak Milik Perindustrian (The Paris Convention for The Protectionof Industrial Property) atau biasa disebut Konvensi Paris dan Konvensi Pendirian World Intellectual Property Organization (WIPO). Ratifikasi Konvensi Paris dan Konvensi Pendirian WIPO berdasarkan Keputusan Presiden Nomor 24 Tahun 1979 yang kemudian diperbaharui dengan keputusan Presiden Nomor 15 Tahun 1997. Berdasarkan Keputusan Presiden Nomor 15 Tahun 1997 inilah Indonesia telah meratifikasi seluruh

\footnotetext{
Loc.Cit.

5 Muhammad Djumhana dan R. Djubaedillah, Op.Cit., hlm. 104.

6 Insan Budi Maulana,Op.Cit.,hlm. 2.

7 Noegroho Amien Soelijarto, "Hukum Paten (Khusus Lingkup Penemu/Pemegang Patendan Lisensi)”. Makalah disampaikan pada Penataran Hukum Perdata dan Ekonomi, Fakultas Hukum UGM, Yogyakarta, 23-30 Agustus 1999, hlm. 9.
} 
ketentuan dalam Konvensi Paris tanpa ada reservasi tertentu. ${ }^{8}$

Pada jaman penjajahan Belanda, Indonesia dengan sendirinya menjadi anggota Uni Paris sejak tahun 1934. Hal itu tidak menyebabkan dengan sendirinya Indonesia menjadi anggota Uni Paris setelah merdeka. Indonesia kembali menjadi anggota Uni Paris pada tahun 1953 berdasarkan permintaan tertulis Pemerintah Indonesia kepada Pemerintah Swiss sebagai negara penyimpan (depository state) perjanjian tersebut. Permintaan tertulis ini dinyatakan melalui surat Pemerintah Indonesia kepada Departemen Politik Konfederasi Swiss tanggal 15 Agustus 1950. ${ }^{9}$

Persiapan pengaturan Paten secara nasional dilakukan secara terpadu dengan persiapan pengaturan hak atas kekayaan intelektual lainnya, yaitu hak cipta dan merek. Berdasarkan Keputusan Presiden Nomor 34 Tahun 1986, dibentuk suatu tim untuk menyiapkan draft Rancangan UndangUndang Paten, Rancangan Undang-Undang Hak Cipta, dan Rancangan Undang-Undang Merek, termasuk mengadakan penelitian dan mendengarkan masukan dari berbagai kalangan dalam rangka menjaring aspirasi masyarakat.

Pada tanggal 1 Nopember 1989, UndangUndang Nomor 6 Tahun 1989 tentang Paten disahkan, dan mulai berlaku pada tanggal 1 Agustus 1991. Undang-Undang Paten tersebut kemudian direvisi dengan UndangUndang Paten Nomor 13 Tahun 1997 pada tanggal 7 Mei 1997. Revisi undang-undang ini didasarkan pada penyesuaian terhadap persetujuan TRIPs (Agreementon Trade Related Aspects of Intellectual Property Right), pemberlakuan secara penuh Konvensi Paris (Paris Convention for The Protection on Industrial Property), dan traktat kerjasama paten atau dikenal dengan PCT (Patent Cooperation Treaty).

Indonesia telah meratifikasi paket persetujuan Putaran Uruguay, yang antara lain memuat persetujuan tentang aspek-aspek dagang Hak atas Kekayaan Intelektual (TRIP's), dengan Undang-Undang Nomor 7 Tahun 1994 Tentang Pengesahan

Syihabuddin, Substansi Pengaturan Paten: Studi terhadap Hukum Paten Indonesia, Jepang dan Amerika Serikat. Fakultas Hukum UII, Yogyakarta, hlm.48.

9 Muhamad Djumhana dan R. Djubaedillah. Op.Cit., hlm.109.
Pembentukan Organisasi Perdagangan Dunia (Agreement Establishing The World Trade Organization). Sebagai konsekuensinya, hal yang berkenaan dengan TRIP's, Indonesia harus mampu melakukan perubahan atau penyempurnaan pada perangkat hukum yang telah ada dibidang Hak Kekayaan Intelektual dan juga mempersiapkan perangkat hukum baru seperti Undang-Undang tentang Desain Produk Industri (IndustrialDesign), UndangUndang tentang Sirkuit Terpadu (Integrated Circuit) dan Undang-Undang tentang Rahasia Dagang (Trade Secrets). Untuk Indonesia, persetujuan TRIP's ini mulai berlaku pada tanggal 1 Januari $2000 .{ }^{10}$

Ratifikasi traktat kerjasama paten (PCT) dilakukan dengan Keputusan Presiden Nomor 16 Tahun 1997 tentang Ratifikasi PCT dan Peraturan-Peraturan dibawahnya. PCT ini memungkinkan suatu hak Paten yang telah diperoleh di suatu negara dapat diakui dan dilindungi diberbagai negara lainnya sekaligus.

Peraturan Paten dalam Undang-Undang Paten No. 6 Tahun 1989 sebagaimana telah diubah dengan Undang-Undang Paten No. 13 Tahun 1997 dirasakan belum sepenuhnya sesuai dengan ketentuan yang tercakup dalam TRIP's. Dengan meratifikasi pendirian W'TO, Indonesia diharuskan menjalankan seluruh ketentuan berkenaan dengan perdagangan Internasional, dan TRIP's merupakan salah satu lampiran dari persetujuan WTO tersebut. Oleh karena itu, pada tanggal 1 Agustus 2001, diundangkan Undang-Undang Paten baru yaitu UndangUndang Nomor 14 Tahun 2001 tentang Paten. Undang-Undang ini mengganti peraturan Paten-Lama secara keseluruhan.

\section{Pokok-pokok Pengaturan Paten Dalam Undang-Undang Paten Nomor 14 Tahun 2001 \\ Subjek Paten}

Berdasarkan pasal 10 Undang-Undang Paten Nomor 14 Tahun 2001, yang berhak memperoleh Paten adalah inventor atau yang menerima lebih lanjut hak inventor yang bersangkutan. Penerimaan lebih lanjut hak

10 Emawati Junus, "Perubahan Atas Undang- Undang Paten Tahun 1989", Jumal Hukum Bisnis. Yayasan Pengembangan Hukum Bisnis, Vol.2/ 1997, hlm.43-44. 
inventor tersebut dapat disebabkan pewarisan, hibah, wasiat atau perjanjian.

Invensi dapat ditemukan dalam kondisi tertentu, misalnya pekerjaan dinas, kontrak kerja, dan sebagainya. Dalam hal ini maka penentuan pemegang paten diatur dalam Undang-Undang Paten Nomor 14 Tahun 2001 sebagai berikut:

a. Jika suatu Invensi dihasilkan oleh beberapa orang secara bersama-sarna, hak atas invensi tersebut dimiliki secara bersama-sama oleh para inventor yang bersangkutan (Pasal 10 ayat (2)).

b. Dalam suatu hubungan kerja, pihak yang memperoleh Paten atas suatu Invensi yang dihasilkan adalah pihak yang memberikan pekerjaan tersebut, kecuali diperjanjikan lain. Ketentuan ini juga berlaku terhadap Invensi yang dihasilkan baik oleh karyawan atau pekerja yang menggunakan data dan atau sarana yang tersedia dalam pekerjaannya sekali pun pekerjaannya itu tidak mengharuskannya untuk menghasilkan invensi (Pasal 12 ayat (1) dan (2). Pekerja sebagai Inventor tersebut berhak mendapatkan imbalan yang layak dengan memperhatikan manfaat ekonomi yang diperoleh dari invensi tersebut Pasal 12 ayat (3).

\section{Objek Paten}

Objek Paten adalah Invensi, yaitu ide inventor yang dituangkan kedalam suatu kegiatan pemecahan masalah yang spesifik di bidang teknologi, dapat berupa produk, proses penyempurnaan, pengembangan produk dan proses.

Dalam Strasbourg Agreement Concerning The International Patent (Konvensi Strasbourg 1971), Invensi sebagai objek paten dapat digolongkan kedalam beberapa seksi dan sub seksi sebagai berikut:

Seksi A :Kebutuhan manusia (buman necessities), mencakup sub-sub seks iagraria (agriculture), bahan-bahan makanan dan tembakau (food stuff sand tobacco), barang-barang perseorangan dan rumah tangga (personl and domestic carticles), kesehatan dan hiburan (bealth and amusement).

Seksi B :Perlaksanaan karya dan pemindahan (performing operation and transporting), mencakup sub-sub seksi pemisahan dan pencampuran (separating andmixing), pembentukan (shaping), pencetakan (printing), perpindahan (transporting), teknologi struktur mikro dan teknologi-nano (Micro-Structural Technology and Nano-Technology).

Seksi C:Kimia dan perlogaman (chemistry and metallurgy), mencakup sub-sub seksi kimia (chemistry) dan perlogaman (metallurgy).

Seksi D:Pertekstilan dan kertas (textiles and paper), mencakup sub-sub seksi pertekstilan dan bahan-bahan pelentur dan yang sejenis (textile sand flexible materials and other wise provided for) dan kertas (paper).

Seksi E:Konstruksi tetap (fixed construction), meliputi sub-sub seksi bangunan (building), pengerukan tanah atau batu dan pertambangan (earthor rock drilling and mining).

Seksi F :Teknik mekanik, pencahayaan, pemanasan, senjata-senjata dan peledakan (mechanical engineering, lighting, heating, weapons, and blasting), meliputi sub-sub seksi mesin-mesin dan pompa-pompa (engines and pumps), pembuatan mesin secara umum (engineering ingeneral), penerangan dan pemanasan (lighting and beating), senjata-senjata dan peledakan (weapons and blasting).

Seksi G:Fisika (physics), mencakup sub-sub seksi instrumentalia (instrument) dan kenukliran (nucleonic).

Seksi H:Listrik (elctricity).

Invensi yang tercakup dalam bidangbidang diatas dapat menjadi objek paten sepanjang memenuhi syarat-syarat substantif tertentu. Paten diberikan untuk invensi yang baru dan mengandung langkah inventif serta dapat diterapkan dalam industri. Suatu invensi mengandung langkah inventif apabila invensi tersebut bagi seseorang yang mempunyai keahlian tertentu dibidang teknik merupakan hal yang tidak dapat diduga sebelumnya.

Pasal 2ayat (3) Undang-Undang Paten Nomor 14 Tahun 2001 menegaskan bahwa panilaian suatu invensi merupakan hal yang tidak dapat diduga sebelumnya harus dilakukan dengan memperhatikan keahlian yang ada pada saat permohonan diajukan atau pada saat permohonan pertama dalam hal 
permohonan itu diajukan dengan hak prioritas.

Adapun yang dimaksud dengan permohonan pertama tersebut adalah permohonan yang telah diajukan untuk pertama kali di negara lain yang merupakan anggota Paris Convention for the Protection of Industrial Property atau anggota World Trade Organization. Indonesia meratifikasi Paris Convention sebagaimana telah beberapa kali diubah dengan Keputusan Presiden Nomor 15 Tahun 1997. Terhadap permohonan paten serupa itu didahulukan hak untuk didahulukan apabila permohonan tersebut diajukan dalam waktu dan dengan syarat-syarat yang ditentukan dalam Undang-Undang Paten.

Dalam hal syarat substantif kebaruan, suatu invensi dianggap baru jika pada penerimaan permohonan paten invensi yang bersangkutan, invensi tersebut tidak sama dengan teknologi yang diungkap sebelumnya.

Teknologi yang diungkap sebelumnya tersebut adalah teknologi yang telah diumumkan di Indonesia atau diluar Indonesia dalam suatu tulisan, uraian lisan, atau melalui peragaan, atau dengan cara lain yang memungkinkan seorang ahli untuk melaksanakan invensi tersebut sebelum tanggal penerimaan atau tanggal prioritas (Pasal 3 Undang-Undang Paten Nomor 14 Tahun 2001).

Teknologi yang diungkap sebelumnya (state of the art atau priorart) mencakup baik berupa literatur Paten maupun bukan. Yang dimaksud dengan tidak sama pada ketentuan Pasal 3 tersebut adalah bukan sekadar beda, tetapi harus dilihat saran atau tidak samanya fungsi cirri teknis (features) invensi tersebut dengan cirri teknis invensi sebelumnya.

Syarat kebaruan ini bersifat relatif, hal ini terlihat dari ketentuan pasal 4 UndangUndang Paten Nomor 14 Tahun 2001 yang menentukan bahwa suatu invensi tidak dianggap telah diumumkan jika dalam jangka waktu paling lama 6 (enarn) bulan sebelum tanggal penerimaan:

a. Invensi tersebut telah dipertunjukkan dalam suatu pameran internasional atau nasional di Indonesia atau diluar negeri yang resmi atau diakui sebagai pameran resmi.

b. Invensi tersebut telah digunakan di Indonesia oleh inventornya dalam rangka percobaan dengan tujuan penelitian dan pengembangan.

Yang dimaksud dengan pameran yang resmi adalah pameran yang diselenggarakan oleh pemerintah; sedangkan pameran yang diakui sebagai pameran resmi adalah pameran yang diselenggarakan oleh masyarakat tetapi diakui atau memperoleh persetujuan pemerintah.

Invensi juga tidak dianggap telah diumumkan apabila dalam jangka waktu 12 (dua belas) bulan sebelum tanggal penerimaan ada pihak lain yang mengumumkan dengan cara melanggar kewajiban untuk menjaga kerahasiaan invensi tersebut.

Pasal 7 Undang-Undang Paten Nomor 14 Tahun 2001 menentukan invensi yang tidak diberikan Paten. Invensi-invensi tersebut adalah invensi tentang:

a. Proses atau produk yang pengumuman dan pelaksanaannya bertentangan dengan perundang-undangan yang ada, moralitas agama, ketertiban umum atau kesusilaan;

b. Metode pemeriksaan, perawatan, pengobatan dan atau pembedahan yang diterapkan terhadap manusia dan atau hewan;

c. Teori dan metode dibidang ilmu pengetahuan dan matematika;

d. Semua makhluk hidup, kecuali jasad renik; atau proses biologis yang esensial untuk memproduksi tanaman atau hewan kecuali proses non biologis atau proses mikrobiologis.

\section{Jenis-jenis Paten}

DalamUndang-Undang Paten Nomor 14 Tahun 2001 dikenal dua bentuk jenis paten, yaitu jenis paten biasa dan jenis paten sederhana. Suatu invensi dikelompokkan sebagai paten sederhana apabila tidak melalui penelitian dan pengembangan yang mendalam. Invensi berupa produk atau alat yang baru dan mempunyai nilai kegunaan praktis sehingga memiliki nilai ekonomis dapat memperoleh perlindungan hukum dalam bentuk paten sederhana terhadap bentuk, konfigurasi, konstruksi atau komponennya.

Objek paten sederhana tidak mencakup proses, penggunaan, komposisi, dan produk yang merupakan hasil proses. Objek paten sederhana hanya dibatasi padahal yang bersifat kasat mata (tangible), bukan yang tidak kasat mata (intangible). 
Pembagian dalam dua jenis paten ini didasarkan kepada segi materi invensi itu sendiri. Dalam hal ini dianut prinsip kebulatan dari suatu invensi (unityofinvention), atau satu paten untuk satu invensi, maka tidak perIu adan ya paten tambahan (patent ofaddition), atau paten perbaikan (patent of improvement).

\section{Jangka Waktu paten}

Menurut pasal 8 Undang-Undang Paten Nomor 14 Tahun 2001, paten biasa diberikan untuk jangka waktu 20 (dua puluh) tahun terhitung sejak tanggal penerimaan. Untuk paten sederhana, pasal 19 menentukan bahwa paten sederhana diberikan untuk jangka waktu 10 (sepuluh) tahun terhitung sejak tanggal penerimaan. Jangka waktu paten tersebut tidak dapat diperpanjang baik untuk jenis paten biasa maupun paten sederhana.

Tanggal mulai dan berakhirnya jangka waktu paten tersebut dicatat dan diumumkan. Pencatatan dilakukan dalam Daftar Umum Paten yang berisi data mengenai bibliografi dan status permohonan, dan surat Paten, yang dibuat dalam bentuk dan susunan yang sederhana, jelas dan rapi. Pengumuman dilakukan dalam berita resmi paten yang diwujudkan dalam suatu jurnal yang diterbitkan secara berkala. Pengumuman ini mencakup informasi tentang bibliografi, spesifikasi, pengalihan, lisensi, pelanggaran, perubahan alamat pemohon atau pemegang paten.

\section{Hak dan Kewajiban Pemegang Paten}

Berdasarkan pasal 16 Undang-Undang Paten Nomor 14 Tahun 2001, Pemegang paten memiliki hak eksklusif untuk melaksanakan paten yang dimilikinya dan melarang pihak lain yang tanpa persetujuannya untuk:

a. Membuat, menggunakan, menjual, mengimpor, menyewakan, menyerahkan, atau menyediakan untuk dijual atau disewakan atau diserahkan produk yang diberi paten.

b. Menggunakan proses produksi yang diberi paten untuk membuat barang atau tindakan lainnya yang dimaksud dalam huruf a.

Hak eksklusif ini dikecualikan terhadap kepentingan pendidikan dan penelitian, hal ini dapat dilihat dalam pasal 16 ayat (3) yang memperbolehkan pemakaian Paten tersebut oleh pihak lain untuk kepentingan pendidikan, penelitian, percobaan, atau analisis sepanjang tidak merugikan kepentingan yang wajar dari pemegang paten.

Ketentuan tersebut dimaksudkan untuk memberikan kesempatan kepada pihak yang memerlukan penggunaan invensi sematamata untuk melakukan penelitian dan pendidikan, selama tidak digunakan untuk kepentingan yang mengarah kepada komersialisasi yang dapat merugikan atau menjadi competitor bagi pemegang paten.

Persetujuan atau izin dari pemegang paten terhadap pihak lain yang ingin melaksanakan paten dilakukan dalam bentuk perjanjian pemberian lisensi. Perjanjian lisensi ini untuk melaksanakan perbuatan sebagaimana yang termuat dalam pasal 16 ayat (1) UndangUndang Paten Nomor 14 Tahun 2001. Lisensi ini pada dasarnya hanya bersifat pemberian hak untuk menikmati manfaat ekonomi dan Paten dalam jangka waktu dan syarat-syarat tertentu berdasarkan perjanjian.

Pemegang paten atau penerima lisensi berhak mengajukan gugatan ganti rugi kepada Pengadilan Niaga setempat terhadap siapapun yang dengan sengaja dan tanpa hak melakukan perbuatan sebagaimana yang dimaksud pasal 16 (pasal 118 ayat (1) UndangUndang Paten Nomor 14 tahun 2001).

Adapun kewajiban Pemegang paten adalah:

a. Membuat produk atau menggunakan proses yang diberi paten di Indonesia, kecuali apabila pembuatan produk atau penggunaan proses tersebut hanya layak dilakukan secara regional.

b. Membayar biaya tahunan untuk pengelolaan kelangsungan berlakunya paten dan pencatatan lisensi (pasal 18 Undang-Undang Paten Nomor 14 Tahun 2001). Biaya ini juga dikenal sebagai biaya pemeliharaan (maintenancefee).

\section{Permohonan Paten}

Permohonan Paten diatur dalam Pasal 20 sampai dengan Pasal 41 Undang-Undang Nomor 14 Tahun 2001 dan Peraturan Pemerintah Nomor 34 Tahun 1991 Tentang Tata Cara Permintaan Paten. Dalam pasal 20 Undang-Undang Paten Nomor 14 Tahun 2001 disebutkan bahwa paten diberikan atas dasar permohonan. Permohonan ini hanya dapat diajukan untuk satu invensi atau beberapa invensi yang merupakan satu kesatuan invensi. 
Permohonan ini diajukan dengan membayar biaya kepada Direktorat Jenderal Hak Kekayaan Intelektual.

Permohonan paten dapat diajukan sendiri oleh inventor, atau bukan inventor. Apabila permohonan diajukan oleh pemohon yang bukan inventor, permohonan tersebut harus disertai pernyataan yang dilengkapi bukti yang cukup bahwa ia berhak atas invensi yang bersangkutan. Dalam hal ini inventor dapat meneliti surat permohonan yang diajukan oleh pemohon bukan inventor dan atas biaya sendiri dapat meminta salinan dokumen permohonan tersebut (Pasal 23 Undang-Undang Paten Nomor 14 Tahun 2001 dan Pasal 2- 3 Peraturan Pemerintah Nomor 34 Tahun 1991).

\section{Persetujuan atau Penolakan Permohon- an}

Persetujuan atau Penolakan Paten diatur dalam Undang Undang Paten Nomor 14 Tahun 2001 Pasal 54-59 dan Peraturan Pemerintah Nomor 34 Tahun 1991 Pasal 5862.

Negara memberikan paten atas suatu invensi setelah menguji bentuk invensi tersebut, apakah patut diberikan paten (suitability for patenting), apakah invensi tersebut mempunyai kebulatan (unity of invention), bagaimana hak ikat dari invensi tersebut untuk mendapatkan paten (subject mailer and patentabilitu). Selain itu pula apakah paten tersebut telah memenuhi persyaratan formal. ${ }^{11}$

Yang dimaksud dengan satu kesatuan invensi atau kebulatan invensi adalah beberapa invensi yang baru dan masih memiliki keterkaitan langkah inventif yang erat.

Apabila hasil pemeriksaan substantif menyimpulkan bahwa invensi telah memenuhi syarat kebaruan, langkah inventif, dan dapat diterapkan dalam kegiatan industri, serta memenuhi ketentuan lain dalam Undang-Undang Paten Nomor 14 Tahun 2001, Direktorat jenderal Hak Kekayaan Intelektual dapat memberikan sertifikat paten kepada pemohon atau Kuasanya. Dalam hal paten sederhana, sertifikat paten sederhana diberikan apabila invensi telah memenuhi syarat kebaruan, dan dapat diterapkan dalam

11 A.Pamuntjak, Sistem Paten: Pedoman Praktek dan Alib Teknologi, EdisiXV, Djambatan, Jakarta, 1994, hlm. 147. kegiatan industri, serta memenuhi ketentuanketentuan paten sederhana (Pasal 55 ayat (1) dan (2) Undang-Undang Paten Nomor 14 Tahun 2001 dan Pasal 58 Peraturan Pemerintah nomor 34 Tahun 1991).

\section{Pengalihan dan Lisensi Paten}

Paten pada dasarnya adalah hak milik perseorangan yang tidak berwujud dan timbul karena kemampuan intelektual manusia. Sebagai hak milik, paten dapat dialihkan oleh pemegangnya kepada pihak lain.

Berdasarkan Pasal 66 Undang-Undang Paten Nomor 14 Tahun 2001, paten dapat beralih atau dialihkan baik seluruhnya atau sebagian karena pewarisan, hibah, wasiat, perjanjian tertulis atau sebab lain yang dibenarkan oleh peraturan perundangundangan.

Segala bentuk peralihan paten ini dicatat dan diumumkan oleh Direktorat Jenderal Hak Kekayaan Intelektual, dan untuk hal tersebut dikenakan biaya. Pengalihan hak tidak menghapus hak inventor untuk tetap dicantumkan nama dan identitasnya dalam paten yang bersangkutan. Inilah yang dimaksud dengan hak moral, yang tidak dapat diubah bahkan setelah berakhirnya perlindungan paten (setelah menjadi milik publik).

Dalam hal lisensi, pemegang paten berhak memberikan lisensi kepada pihak lain berdasarkan perjanjian lisensi (Pasal 69 ayat (1) Undang-Undang Paten Nomor 14 Tahun 2001). Berbeda dari pengalihan paten, lisensi pada dasarnya hanya bersifat pemberian hak untuk menikmati manfaat ekonomi dari paten dalam jangka waktu tertentu dan syaratsyarat tertentu pula.

\section{Pembatalan Paten}

Pembatalan paten dapat berupa batal demi hukum, batal atas permohonan pemegang paten,dan batal berdasarkan gugatan. Hal ini diatur dalam Bab V1 Pasal 88-98 UndangUndang Paten Nomor 14 Tahun 2001.

Batal demi hukum terjadi apabila pemegang paten tidak memenuhi kewajibannya membavar biaya tahunan dalam jangka waktu yang ditentukan dalam UndangUndang Paten. Batal atas permohonan pemegang paten diajukan secara tertulis kepada Dirjen Hak kekayaan Intelektual dan hanya jika penerima lisensi memberikan persetujuan 
secara tertulis yang dilampirkan pada permohonan pembatalan tersebut.

Gugatan pembatalan paten dapat dilakukan oleh pihak ketiga kepada pemegang paten melalui Pengadilan Niaga dalam hal terjadi pelanggaran syarat-syarat pemberian paten sebagaimana diatur Undang-Undang Paten ini dalam Pasal 2,6,dan7. Pemegang paten atau penerima lisensi dapat mengajukan gugatan pembatalan paten lain yang sama dengan patennya kepada Pengadilan Niaga. Jaksa dapat mengajukan gugatan pembatalan terhadap pemegang paten atau penerima lisensi kepada Pengadilan Niaga dalam hal pelaksanaan paten merugikan kepentingan masyarakat.

Dalam hal pembatalan salah satu paten dari dua paten yang sama dengan pemegang paten berbeda, lisensi tetap berjalan berdasarkan perjanjian, namun pembayaran royalty dari pemegang lisensi diserahkan kepada pemegang paten yang patennya tidak dibatalkan.

\section{Penyelesaian Sengketa Paten}

Penyelesaian sengketa dalam bidang paten pada dasarnya diselesaikan melalui gugatan kepada Pengadilan Niaga berdasarkan Pasal 117 ayat (1) Undang-Undang Paten Nomor 14 Tahun 2001. Namun tidak menutup kemungkinan adanya penyelesaian melalui arbitrase atau alternatif penyelesaian sengketa berdasarkan Pasal tersebut.Alternatif penyelesaian sengketa tersebut dapat berupa negosiasi, mediasi, konsiliasi, dan cara lain yang dipilih oleh para pihak sesuai dengan Undang-Undang yang berlaku.

Hak menggugat dalam sengketa paten berlaku surut sejak tanggal penerimaan (Pasal 117 ayat (2) Undang-Undang Paten Nomor 14 Tahun 2001). Dan apabila telah terdapat putusan atas gugatan, putusan diberitahukan kepada para pihak paling lama 14 (empatbelas) hari sejak putusan dijatuhkan .Putusan tersebut selanjutnya dicatat dan diumumkan oleh Direktorat Jenderal Hak kekayaan Intelektual.

Berdasarkan Pasal 119 ayat (1) UndangUndang Paten Nomor 14 Tahun 2001, dalam hal pemeriksaan gugatan terhadap paten-proses, kewajiban pembuktian bahwa suatu produk tidak dihasilkan dengan menggunakan paten-proses dibebankan kepada pihak tergugat apabila:

a. Produk yang dihasilkan melalui patenproses merupakan produk baru, b. Produk tersebut diduga merupakan hasil dari paten-proses, sekalipun telah dilakukan upaya pembuktian yang cukup untuk itu, pemegang paten tetap tidak dapat menentukan proses apa yang digunakan untuk menghasilkan produk tersebut.

Ketentuan pembuktian terbalik tersebut diterapkan mengingat sulitnya penanganan sengketa paten untuk proses. Sekalipun demikian, untuk menjaga keseimbangan kepentingan yang wajar diantara para pihak, hakim tetap diberi kewenangan memerintahkan kepada pemilik paten untuk terlebih dahulu menyampaikan bukti salinan sertifikat paten bagi proses yang bersangkutan, serta bukti awal yang memperkuat dugaanini. Selainitu, hakim juga wajib mempertimbangkan kepentingan pihak tergugat untuk memperoleh perlindungan terhadap kerahasiaan proses yang telah diuraikannya dalam rangka pembuktian yang harus dilakukannya dipersidangan.

Dalam Penjelasan Pasal 119 Ayat (3) UndangUndang Paten Nomor 14 Tahun 2001 disebutkan bahwa perlindungan terhadap kerahasiaan proses yang belum atau tidak dipatenkan itu sangat penting mengingat sifat suatu proses pada umumnya sangat mudah dimanipulasi atau disempurnakan oleh orang yang memiliki pengetahuan yang umum dibidang teknik atau teknologi tertentu. Dengan demikian, atas permintaan para pihak, hakim dapat menetapkan agar persidangan dinyatakan tertutup untuk umum.

Gugatan didaftarkan kepada Pengadilan Niaga dengan membayar, biaya gugatan. Atas dasar pendaftaran itu, paling lama 14 (empatbelas) hari kemudian Pengadilan Niaga harus sudah menetapkan hari sidang, dan sidang pemeriksaan gugatan dimulai paling lama 60 (enam puluh) hari sejak pendaftaran gugatan.

Putusan atas gugatan harus diucapkan paling lama 180 (seratus delapan puluh) hari setelah tanggal pendaftaran gugatan. Terhadap putusan Pengadilan Niaga ini hanya dapat dilakukan upaya hukum kasasi.

Pengadilan dapat menetapkan beberapa penetapan yang sifatnya sementara dalam hal terjadinya pelanggaran paten. Berdasarkan Pasal 125 Undang-Undang Paten Nomor 14 Tahun 2001, atas permintaan pihak yang merasa dirugikan karena pelaksanaan paten, Pengadilan Niaga dapat menerbitkan surat penetapan yang segera dan efektif untuk: 
a. Mencegah berlanjutnya pelanggaran paten dan hak yang berkaitan dengan paten, khususnya mencegah masuknya barang yang diduga melanggar paten dan hak yang berkaitan dengan paten kedalam jalur perdagangan termasuk melakukan importasi.

b. Menyimpan bukti yang berkaitan dengan pelanggaran paten dan hak yang berkaitan dengan paten tersebut guna menghindari terjadinya penghilangan barang bukti.

c. Meminta kepada pihak yang merasa dirugikan agar memberikan bukti yang menyatakan bahwa pihak tersebut memang berhak atas paten dan hak yang berkaitan dengan paten, serta hak pemohon tersebut memang sedang dilanggar.

Ketentuan ini dimaksudkan untuk mencegah terjadinya kerugian yang lebih besar pada pihak yang dilanggar Paten atau haknya. Atas permintaan pemohon, Pengadilan Niaga berwenang menerbitkan penetapan sementara untuk mencegah berlanjutnya pelanggaran dan masuknya barang yang diduga melanggar paten ke jalur perdagangan termasuk tindakan importasi.

\section{KetentuanPidana}

Ketentuan pidana dalam Undang-Undang Paten Nomor 14 Tahun 2001 diatur dalam Bab XV Pasal 130-135. Tindak pidana dalam paten tersebut adalah sebagai berikut:

a. Barangsiapa dengan sengaja dan tanpa hak melanggar hak pemegang paten dengan melakukan salah satu tindakan sebagaimana dimaksud dalam Pasal 16 dipidana dengan pidana penjara paling lama 4 (empat) tahun dan atau denda paling banyak Rp.500.000.000,00(lima ratus juta rupiah). (Pasal 130)

b. Barangsiapa dengan sengaja dan tanpa hak melanggar hak pemegang paten sederhana dengan melakukan salah satu tindakan sebagaimana dimaksud dalam Pasal 16 dipidana dengan pidana penjara paling lama 2 (dua) tahun dan atau denda paling banyak Rp.250.000.000,00 (dua ratus lima puluh juta rupiah). (Pasal 131)

c. Barangsiapa dengan sengaja tidak mampu memenuhi kewajiban sebagaimana yang dimaksud dalam Pasal 25 ayat (3), Pasal 40, dan Pasal 41,dipidana dengan pidana penjara paling lama 2 (dua) tahun. (Pasal 132)

\section{Penyempurnaan, Penambahan, dan Penghapusan Beberapa Ketentuan Undang- Undang Paten Nomor 14 Tahun 2001 terhadap Undang-Undang Paten-Lama \\ a.Penyempurnaan}

UU Paten Nomor 14 Tahun 2001 digunakan istilah invensi dan inventor untuk menggantikan istilah penemuan dan penemu. Alasan penggantiannya adalah bahwa istilah invensi dan inventor lebih tepat merujuk kepada hasil dan pelaku serangkaian kegiatan yang menciptakan suatu yang baru. Istilah invensi dan inventor ini juga sudah terdapat dalam Kamus Besar Bahasa Indonesia.

Istilah Kantor Paten dalam UU Paten-Lama diubah menjadi Direktorat Jenderal, dimaksudkan untuk mempertegas institusi hak kekayaan intelektual sebagai satu kesatuan sistem.

Penyempurnaan lain ialah mempersingkat jangka waktu pemeriksaan substantif atas paten sederhana yang semula 36 (tiga puluh enam) bulan menjadi 24 (dua puluh empat) bulan terhitung sejak tanggal penerimaan.

\section{b.Lisensi Wajib}

Undang-undang Paten Nomor 14Tahun 2001 menentukan bahwa instansi pemberi lisensi wajib adalah Direktorat Jenderal Hak Kekayaan Intelektual, bukan lagi Pengadilan Negeri sebagaimana ketentuan Undang-undang Paten-Lama.Maksudnya adalah untuk penyederhanaan prosedur dan peningkatan layanan terhadap masyarakat.

\section{c. Penyelesaian Sengketa Diluar Peng- adilan}

Undang-Undang Paten Nomor 14 Tahun 2001 membuka kemungkinan untuk menyelesaikan sengketa diluar pengadilan, seperti melalui arbitrase atau alternative penyelesaian sengketa.

\section{d.KetentuanPidana}

Undang-Undang Paten Nomor 14 Tahun 2001 mengatur hal-hal yang tidak dikategorikan tindak pidana, yaitu hal yang berkaitan dengan kepentingan kesehatan masyarakat. Disamping itu tindak pidana dalam Undang-undang ini dikategorikan sebagai delik aduan. 


\section{e. Penghapusan}

Dalam Undang-Undang Paten Nomor 14 Tahun 2001 terdapat beberapa penghapusan terhadap ketentuan Undang-Undang PatenLama yang dinilai tidak sejalan dengan persetujuan TRIPs (Trade Related Aspect Of Intellectual Property Rights), yaitu mengenai penundaan pemberian paten.

\section{Kesimpulan}

Tinjauan umum tentang paten berdasarkan Undang-Undang No. 14 Tahun 2001 dalam tulisan ini meliputi sejarah perkembangan pengaturan paten, pengertian, jenis, pendaftaran, pengalihan dan lisensi paten serta pelaksanaan paten oleh pemerintah. Seiring perkembangan teknologi yang sangat besar terhadap kehidupan sehari-hari, yang mana perkembangan teknologi tersebut sangat pesat dirasakan perlu melahirkan peraturan tersendiri mengenai paten.

Pada tahun 1989 diundangkanlah UndangUndang No. 6 Tahun 1989 yang kemudian diubah ke Undang-Undang No. 13 tahun 1997. Namun perkembangan teknologi yang semakin maju undang-undang tersebut dirasa tidak sesuai lagi dan perlu melakukan perubahan, sehingga pada tahun 2001 diundangkan kembali undangundang terbaru tentang paten yaitu Undangundang No.14 Tahun 2001. Pengertian Paten adalah hak eksklusif yang diberikan oleh negara kepada inventor atas hasil invensinya di bidang teknologi, yang untuk selama jangka waktu tertentu melaksanakan sendiri invensinya tersebut atau memberikan persetujuannya kepada pihak lain untuk melaksanakannya.

Bentuk-bentuk pelanggaran paten berupa membuat, menggunakan, menjual, mengimpor, menyewakan, menyerahkan, atau menyediakan untuk dijual atau disewakan atau diserahkan produk yang diberi paten (dalam paten-produk) dan menggunakan proses produksi yang diberi paten untuk membuat barang dan tindakan membuat, menggunakan, menjual, mengimpor, menyewakan, atau menyediakan untuk dijual atau disewakan atau diserahkan proses produksi yang telah diberi paten.

Pada pasal 133 Undang-Undang No.14 Tahun 2001 Tentang Paten menentukan tindak pidana paten merupakan delik aduan.Pemegang paten akan mendapatkan surat pendaftaran penemuan, yang mana surat pendaftaran ini dapat dijadikan sebagai alat bukti awal di pengadilan apabila timbul sengketa di kemudian hari terhadap penemuan tersebut. Perlindungan terhadap paten meliputi perlindungan dalam kerangka nasional yaitu berdasarkan Undangundang No. 14 tahun 2001.

\section{Daftar Rujukan}

Djumhana, Muhammad dan Djubaedillah, R, Hak Milik Intelektual, Sejarah, Teori dan Prakteknya di Indonesia, Bandung, PT. Citra Aditya Bakti, 1997.

Gautama, Sudargo, Hak dan Perjanjian Internasional : TRIPS, GATT, Putaran Uruguay, Bandung, PT. Citra Aditya Bakti, 1994.

Junus, Emawati, "Perubahan Atas Undangundang Paten 1989", Jurnal Hukum Bisnis, Vol. 2, Yayasan Pengembang Hukum Bisnis, 1997.

Maulana, Insan Budi, "Penerapan Paten Sejak UU Paten No. 6 Tahun 1989 hingga UU Paten No. 13 Tahun 1997, Pengalaman Indonesia SelamaIni, Kapita Selekt Hak Kekayaan Intelektual I, Yogyakarta, Yayasan Klinik Haki, Jakarta PSH IH UII Yogyakarta, 2000.

Pamuntjah, A. Sistem Paten :Pedoman, Praktek dan Alih Teknologi, Edisi XV Jakarta, Djambaten, 1994.

Peraturan Pemerintah No. 34 Tahun 1991 tentang Tata Cara Peraturan Paten (Lembaran Negara Rahun 1991 No. 421).

Saetijarto, Nugroho Amien, "Hukum Paten (KhususLingkupPenemu, Pemegang Paten danLisensi)"

PeraturanHukumPerdatadanEkonomi, FakultasHukum UGM, Yogyakarta, 22-23 Agustus 1999.

Syihabuddin, Substansi Pengatur Paten :Studi Terhadap Hukum Paten Indonesia, Jepang dan Amerika Serikat, Fakultas Hukum UII Yogyakarta, 2001.

Undang-undang No. 6 Tahun 1989 tentang Paten (Lembaran Negara Tahun 1989 No. 3.)

Undang-undang No. 131997 tentang perubahan atas Undang-undang No. 6 Tahun 1989 tentang Paten (Lembaran Negara Tahun 1997 No. 30)

Undang-undang No. 14 Tahun 2001 tentang Paten (Lembaran Negara Tahun 2001 No. 109) 